\title{
A new species and section of Utricularia (Lentibulariaceae) from northern Australia
}

\section{Allen Lowrie', Ian D. Cowie ${ }^{2}$ and John G. Conran ${ }^{3}$}

\author{
${ }^{1} 6$ Glenn Place, Duncraig, W.A. 6023 Australia \\ ${ }^{2}$ Northern Territory Herbarium, Department of Natural Resources, Environment and the Arts, \\ P.O. Box 496, Palmerston N.T. 0831 Australia \\ ${ }^{3}$ Australian Centre for Evolutionary Biology and Biodiversity, Environmental Biology, DP 312, \\ School of Earth and Environmental Sciences, The University of Adelaide, S.A. 5005 Australia \\ Author for correspondence: john.conran@adelaide.edu.au
}

\begin{abstract}
A minute, reddish-purple-flowered, new species of Utricularia L. subgenus Utricularia (Lentibulariaceae) is described and illustrated: Utricularia simmonsii Lowrie, Cowie \& Conran from the western Top End of the Northern Territory and near Lockhart River and Tozer's Gap, Iron Range in far north Queensland. The species represents possibly the world's smallest-flowered carnivorous plant. It shows some affinities to Utricularia sections Enskide and Pleiochasia, but possesses a combination of features not found in any other Utricularia species. The tiny flowers have an open, gullet throat, virtually lack a spur (both unusual features in the genus), the traps lack obvious trigger or guiding hairs, and the seeds have almost fingerprint-like swirled sculpturing. Because of its distinctness, it is placed into a new section: Minutae Lowrie, Cowie \& Conran. A key to the Utricularia taxa found in Northern Australia is also provided.
\end{abstract}

\section{Introduction}

The genus Utricularia with over 220 species worldwide is well represented in Australia with Taylor (1989) listing 64 species, and two more described since then (Lowrie 1998a, $\mathrm{b}, 2002$ ), bringing the current total to 66 species in 13 sections. There are also numerous undescribed taxa from the Australian tropics (R. Barrett, D. Dixon and J. Clarkson pers. comm.).

The monsoonal Top End of the Northern Territory (NT) has been identified as a world centre of diversity for the genus Utricularia L. (Lentibulariaceae) with 36 taxa known

Paper from the Australian Systematic Botany Society Conference held in Cairns, November 2006 
from the area (Taylor 1989). Indeed, the area supports a diverse assemblage of specialist plant species on seasonally waterlogged, infertile, sandy soils particularly associated with the lowlands of the Koolpinyah Surface of Williams (1969) as well as the Western Arnhem Land Plateau. Many of the taxa involved are endemic to the NT (Woinarski et al. 2006). The habitat is extensive and finely divided by subtle gradients in soil texture, drainage, period of inundation and water flow. This in turn influences the species composition across the landscape and appears to have allowed a rich flora to develop. During studies of the effects of sand mining on this habitat an undescribed species of Utricularia was seen in the field and collections were subsequently made over a number of years.

Similarly, in October 2005, the same minute-flowered new species of Utricularia was found growing with cultivated material of a much larger-flowered Utricularia species from Turtle Creek crossing, Iron Range. It was also found near the Lockhart River community refuse site; and along the Lockhart River near Tozer's Gap in far north Queensland (Fig. 1).

When compared against Taylor's (1989) monograph of Utricularia, these collections clearly represented a new taxon quite unlike any previously described species. Taylor records six tiny-flowered Utricularia in his monograph:U. albiflora R.Br. (fig. 28, p. 151), U. quinquedentata F. Muell. (fig. 29, p. 153) from Australia; U. cymbantha Oliver (fig. 208 , p. 680) from Africa; U. naviculata P. Taylor (fig. 209, p. 682) from South America; U. biovularioides (Kuhlum.) P. Taylor (fig. 210, p. 684) from South America; and U. olivacea Wright ex Griseb. (fig. 211, p. 687) from the Americas. U. quinquedentata and the closely-related $U$. albiflora were previously regarded as the smallest in the genus, but the new species is shorter in stature and has a smaller corolla. When these other species are compared to the new taxon, the minute corolla size of the latter easily make it the world's consistently smallest-flowered Utricularia (and carnivorous plant) species so far discovered.

Accordingly, the new species is named here and its affinities to the remainder of the genus are discussed. A key to the 45 Utricularia species found in northern Qld, the NT and the Kimberley Region of WA is provided here to enable identification.

\section{Methods}

Morphological characters were examined at DNA and ADU using fresh, dried and spiritpreserved material, and seeds were examined under scanning electron microscopy.

The terminology used for Utricularia follows that generally accepted for the genus (Taylor 1989). Specifically, rhizoids in Utricularia resemble and function as roots; scales may be present on the peduncle (or inflorescence stalk); a bract can be found opposite or subtending each flower pedicel and often two bracteoles occur laterally to the bract.

\section{Taxonomy}

Utricularia simmonsii Lowrie, Cowie \& Conran sp. nov.

Herba minuta. Folia angustissima filiformia, rariora oblonga. Vesiculae nudae vel glandulis sessilibus dispersis; appendix dorsalis singula; saetae irretitantes papillatae. 


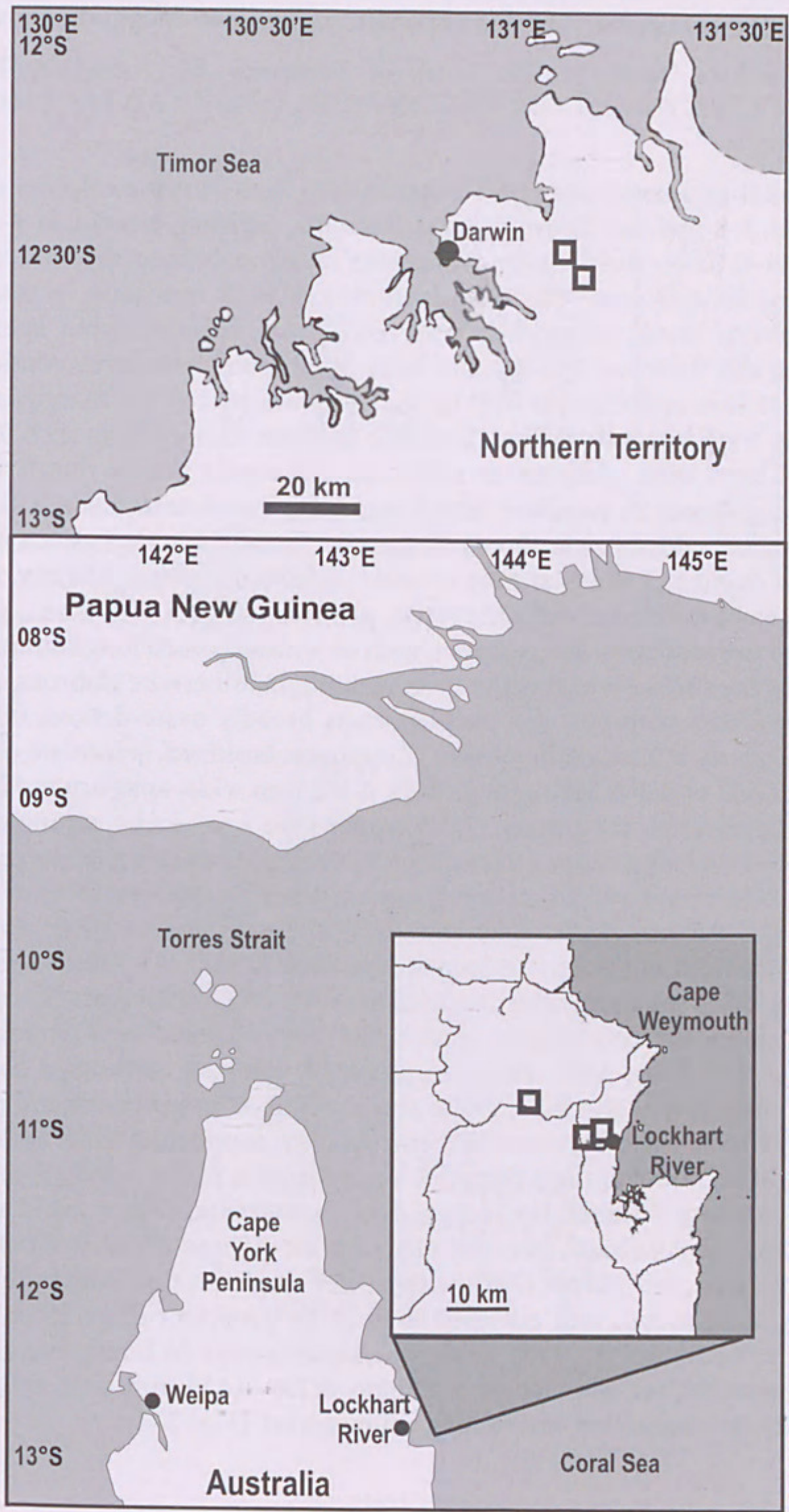

Fig. 1. Maps showing the current known distribution for Utricularia simmonsii in the Northern Territory and Queensland. 
Flores 1-2(-3) minutissimi, purpureo-rubri. Corolla cucullata; calcar vel faux clausa deficiens; labium inferum integrum limbo diminuto. Stamina et stylus per corollam inclusus attamen conspicuus. Semina turbinata, mellea, testa longitudinaliter striata.

Holotype: Northern Territory: $1 \mathrm{~km}$ north of Girraween Rd - Anglesey Rd corner, $12^{\circ} 30^{\prime} \mathrm{S} 131^{\circ} 06^{\prime} \mathrm{E}$, R.K. Harwood 1550, 3 June 2006 (DNA). Isotypes: AD, BRI, CANB, K, MEL, MO, NSW, PERTH.

Small perennial or annual (some NT populations) herb forming colonies up to $1 \mathrm{~m}$ diameter and 3-8 $\mathrm{mm}$ tall above ground. Rhizoids, capillary, simple, to $8 \mathrm{~mm}$ long, tapering, $0.04-0.1 \mathrm{~mm}$ diam. Stolons reticulate, capillary, branched or not, c. $0.1 \mathrm{~mm}$ diam., internodes 1-3 mm long. Leaves solitary, 3.5-15 $\mathrm{mm}$ long in total, petiole indistinct, lamina linear, dimorphic, 1-nerved, mostly filiform, terete, apex acicular, rarely oblong and flattened, $0.3-0.4 \mathrm{~mm}$ wide, apex acute, sometimes rounded. Traps scattered on stolons and rhizoids with up to 6 on lower part of leaf margins, stipe 0.1$0.5 \mathrm{~mm}$ long, traps upwards-facing, dimidiate to ovate with a falcate apex, $0.2-0.5 \mathrm{~mm}$ long, $0.2-0.3 \mathrm{~mm}$ wide, glabrous or with scattered sessile glands; dorsal appendage short, obtuse, glabrous or papillate; lateral appendages and ventral wings absent; trap orifice hyaline or reddish-pink, threshold glands 1-armed, internal glands bifid, arms ellipsoid and ovoid c. 3 times as long as wide. Inflorescence erect, solitary, 1-2(rarely 3)-flowered, 6-17 mm long, peduncle terete, glabrous, 0.1-0.3 mm diam., green, redpurple ( $\left.{ }^{7} 72 \mathrm{~B}\right)$ towards apex, scales absent, with or without raised longitudinal verrucae scattered over the surface which shine silver in sunlight, otherwise glabrous. Bracts and bracteoles basifixed, glabrous, red-purple; bracts broadly ovate-deltoid, $0.3-0.5 \mathrm{~mm}$ long, apex acute or \pm 3 -lobed; bracteoles 2 , opposite, basifixed, lanceolate or subulate, c. $0.25 \mathrm{~mm}$ (Qld) or 0.4-0.5 mm long (NT), c. $0.2 \mathrm{~mm}$ wide, apex acute. Flowers 1-3. Calyx lobes 2, unequal, red-purple (72B); upper lobe \pm orbicular, strongly concavoconvex, $0.75-1 \mathrm{~mm}$ long and apex truncate (NT) or elliptic, apically \pm acute and involute (Qld); lower lobe broadly elliptic, concavo-convex, $0.5-0.75 \mathrm{~mm}$ long (NT) or 1-1.2 mm long (Qld), 0.7-0.8 mm wide, apex rounded or emarginate, revolute. Corolla redpurple (72B), paler at very base, two lipped, connate at base, $0.7-1.3 \mathrm{~mm}$ long; upper lip ovate-oblong, $0.7-1 \mathrm{~mm}$ long, apex rounded to retuse (NT) or involute (Qld); lower lip $0.8-1.3 \mathrm{~mm}$ long, broadly elliptic, entire, the limb reduced to a narrow reflexed margin c. $0.5 \mathrm{~mm}$ long, apex obtuse to rounded, glabrous, without a conspicuous rim, shorter than lower calyx lobe; palate absent (Qld) or conspicuous and red-purple (NT); Spur virtually absent. Stamen filaments 2, white, supporting white anthers visible within the corolla hood, anthers posterior to the stigma, pollen white, 5-6-colporate, obloid, c. $22 \mu \mathrm{m}$ long. Style red, lingulate, anteriorly stigmatic. Ovary, ovoid, unilocular, c. $0.3 \mathrm{~mm}$ long, placenta basal, free, globular. Capsule globose-ovoid, $0.6-0.8 \mathrm{~mm}$ long, 0.6-0.75 mm diam., red-purple (72B) with a paler single ventral, longitudinal, elliptic pore, drying stramineous and enclosed in fruit by persistent calyx lobes, dehiscent (NT) or indehiscent (Qld). Seeds numerous, stramineous to honey-brown, broadly ellipsoid to obovoid, sub-angular, or turbinate, $0.125-0.175 \mathrm{~mm}$ long, cells elongate, longitudinally striate-swirled, resembling a fingerprint. (Figs 2-4)

${ }^{1}$ Royal Horticultural Society London. 1966. R.H.S. Colour Chart in association with the Flower Council of Holland. Published by The Royal Horticultural Society LONDON and Flower Council of Holland LEIDEN. 

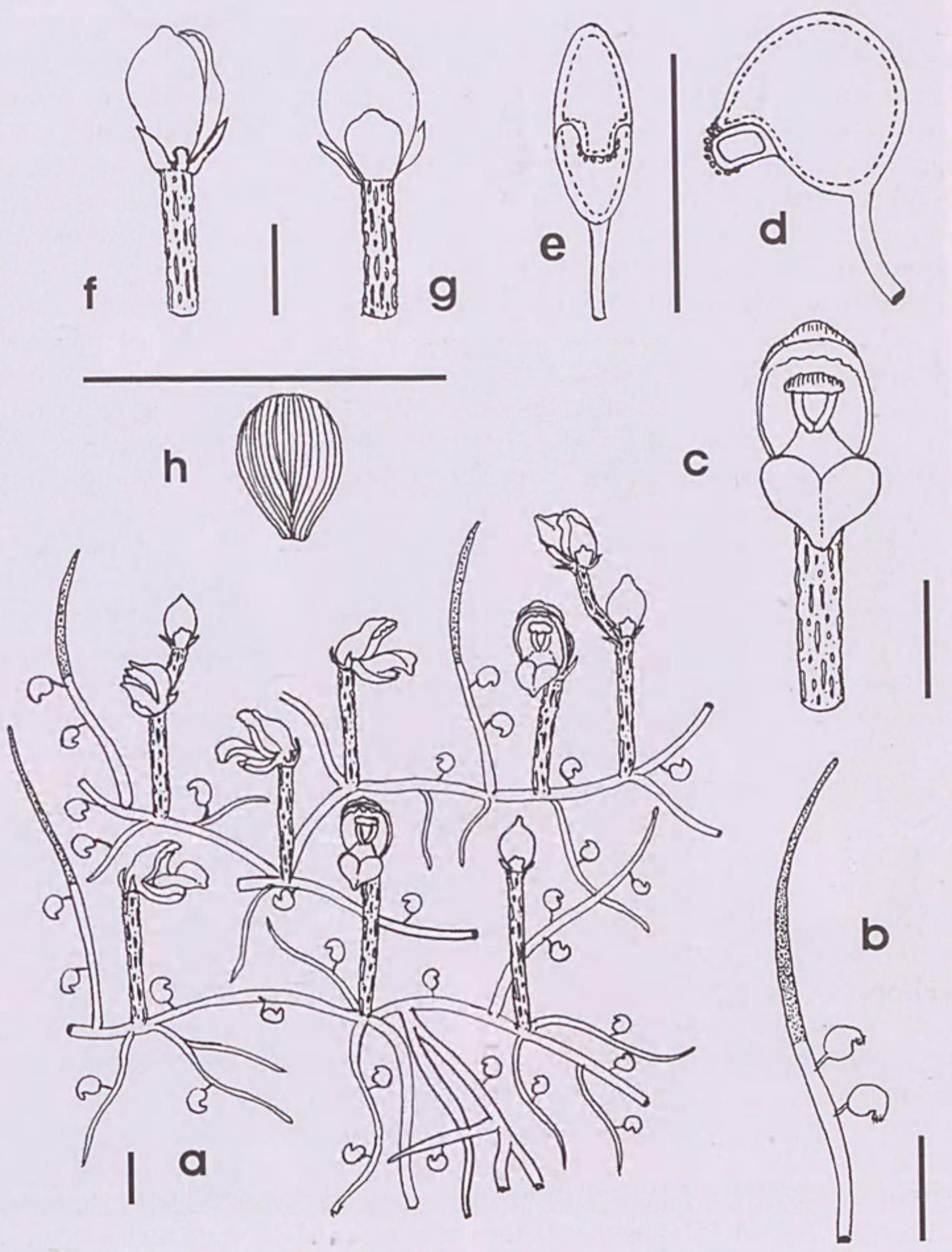

Fig. 2. Utricularia simmonsii: a, plant; b,leaf; c, corolla; d, side view of trap; e, front view of trap; f, bracteoles; $\mathrm{g}$, bract; $\mathbf{h}$, seed; Scale bars for $\mathrm{d}, \mathrm{e} \& \mathrm{~h}=0.5 \mathrm{~mm}$, all other scale bars $=1 \mathrm{~mm}$. Drawn from live, cultivated material, ex Paul Simmons, from Lockhart River, far north Queensland by A. Lowrie 2005. Voucher A. Lowrie 3159 \& P. Simmons (BRI, PERTH, MEL. K). 


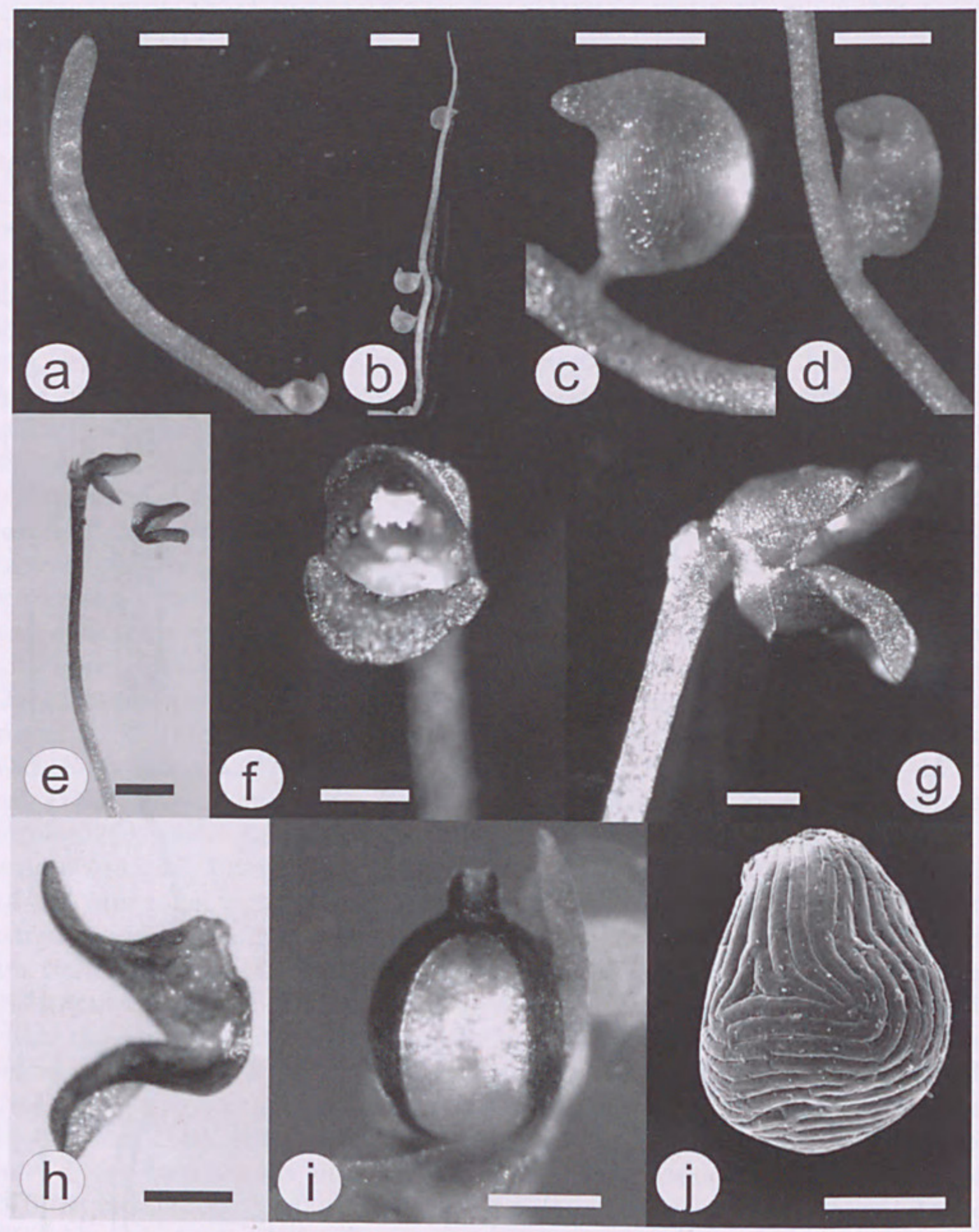

Fig. 3. Utricularia simmonsii: a, leaf and trap; b, leaf and traps; c, trap, lateral view; d, trap; e, flowering peduncle; $f$, flower; $g$, flower, lateral view; $h$, corolla, lateral view; $i$, nearly mature capsule (enclosing calyx removed) showing lateral longitudinal pore; $\mathbf{j}$, seed. Scale bars for a, b $\& \mathrm{e}=1, \mathrm{c}, \mathrm{d} \& \mathrm{i}=0.25 \mathrm{~mm}, \mathrm{f}-\mathrm{h}=0.5 \mathrm{~mm}, \mathrm{j}=50 \mu \mathrm{m}$. Vouchers a-h, Harwood 1550 (DNA); i-j, A. Lowrie 3159 \& P. Simmons (BRI, PERTH, MEL. K). 

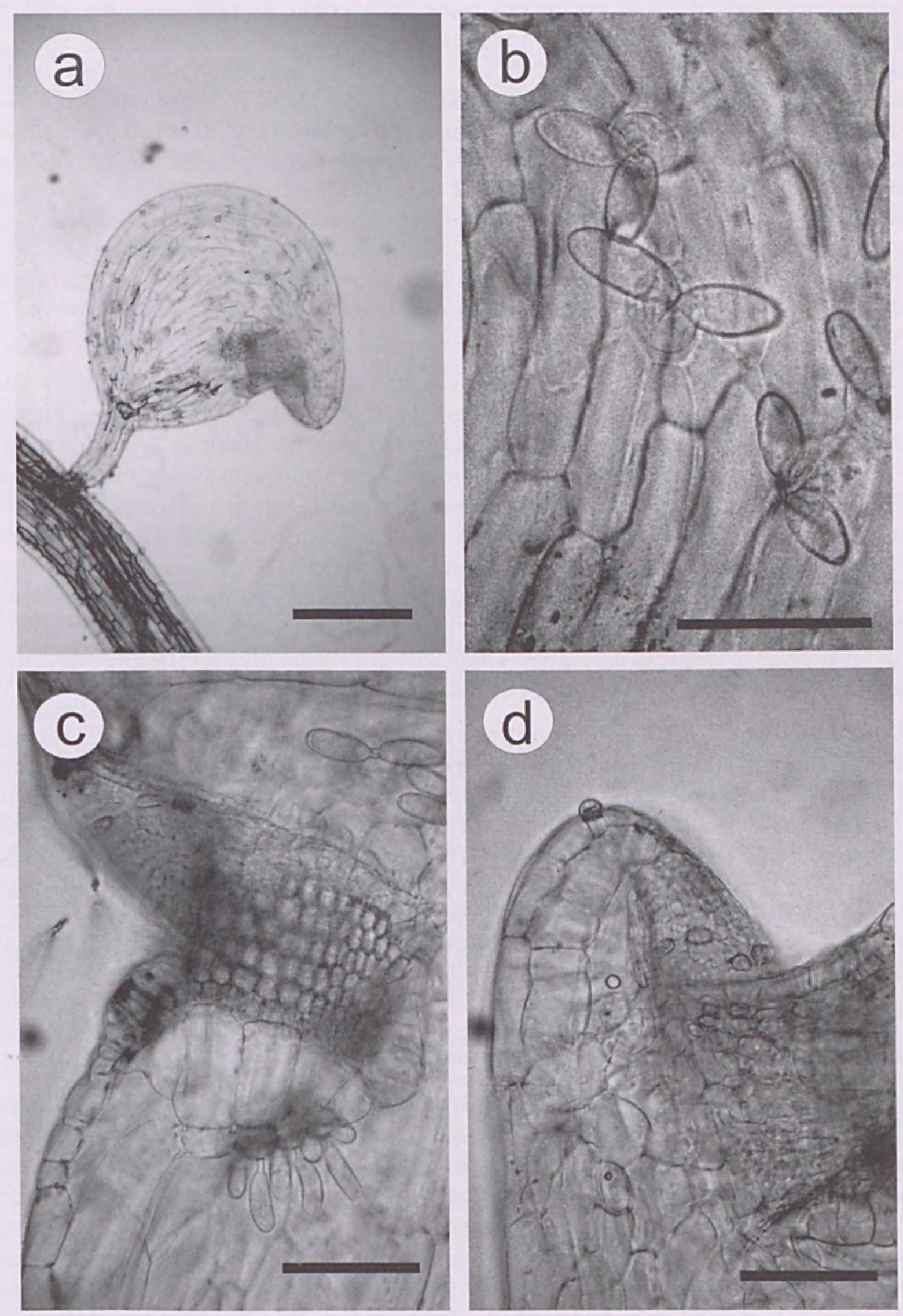

Fig. 4. Utricularia simmonsii: a, trap; b, trap internal bifid glands; $\mathbf{c}$, trap orifice and 1-armed threshold glands; $\mathbf{d}$, dorsal process of trap showing external glandular trichomes. All to indicated scales. Photographed from live, cultivated material, ex Paul Simmons, from Lockhart River, far north Queensland. Scale bar for $\mathrm{a}=100 \mu \mathrm{m}, \mathrm{b}-\mathrm{d}=20 \mu \mathrm{m}$. Voucher A. Lowrie 3159 \& P. Simmons (BRI, PERTH, MEL. K). 
Other specimens examined: Northern Territory: Howard River Hunting Reserve, $12^{\circ} 26^{\prime} \mathrm{S}$, $131^{\circ} 04^{\prime}$ E, 7 Jul 1995, J.L. Egan 5133 \& I.D. Cowie (DNA); 1 km. N of Girraween Rd., 1 km. W of Howard River, $12^{\circ} 30^{\prime} \mathrm{S}, 131^{\circ} 06^{\prime} \mathrm{E}, 17$ May 1996, R.K. Harwood 145 (DNA); $1 \mathrm{~km}$ north of Girraween Rd - Anglesey Rd corner, 12³0'S 131 ${ }^{\circ} 06^{\prime} \mathrm{E}, 3$ May 2001, R.K. Harwood 1084 (DNA); $1 \mathrm{~km}$ north of Girraween Rd - Anglesey Rd corner, $12^{\circ} 30^{\prime} \mathrm{S} 131^{\circ} 06^{\prime} \mathrm{E}, 7$ May 2002, I.D. Cowie 10646 (DNA); $1 \mathrm{~km}$ north of Girraween Rd - Anglesey Rd corner, $12^{\circ} 30^{\prime} \mathrm{S} 131^{\circ} 06^{\prime} \mathrm{E}, 16$ Jun 2006, R.K. Harwood 1564 (DNA). Queensland: Turtle Creek crossing, Iron Range, c. 7.25 km NW of Lockhart River township, north Queensland, $12^{\circ} 46^{\prime} \mathrm{S}, 143^{\circ} 17^{\prime} \mathrm{E}$, A. Lowrie 3159 \& P. Simmons, 28 Oct 2005 (BRI, PERTH, MEL, K); Tozer's Flat, Pascoe River, c. 17.7 km NW of Lockhart River township, north Queensland, $12^{\circ} 43^{\prime} \mathrm{S}, 143^{\circ} 12^{\prime} \mathrm{E}$, A. Lowrie 3213 \& P. Simmons, 28 Oct 2005 (BRI, PERTH, MEL, K); Iron Range, near Lockhart River community refuse site, c. $1.2 \mathrm{~km}$ NW of Lockhart River township, north Queensland, $12^{\circ} 47^{\prime} \mathrm{S}, 143^{\circ} 20^{\prime} \mathrm{E}$, A. Lowrie 3214 \& P. Simmons, 28 Oct 2005 (BRI, PERTH, MEL, K).

Distribution and ecology: the species occurs in the NW Northern Territory and on Cape York Peninsula, Queensland (Fig 1). In the Northern Territory it is known from only two localities on sand sheets associated with the Howard River floodplain in the Darwin rural area, where it grows in short herbland with Bergia pusilla Benth. (Elatinaceae), Centrolepis exserta (R.Br.) Roem. \& Schult. (Centrolepidaceae), Eriocaulon cinereum R.Br. (Eriocaulaceae), Trithuria lanterna D.A.Cooke (Hydatellaceae) and Utricularia chrysantha R.Br., on almost pure sand just above the receding water line. These populations occur in seasonally inundated depressions formed in abandoned sand extraction excavations, on the upper margin of a non-estuarine floodplain. The species appears to flower later and perhaps occurs in a seasonally more deeply inundated habitat than many other attached NT Utricularia species.

Utricularia simmonsii is also known from three locations near the town of Lockhart River ( $\left.12^{\circ} 47^{\prime} \mathrm{S} 143^{\circ} 21^{\prime} \mathrm{E}\right)$, Iron Range on Cape York. There, the species grows in a mixture of fine sand and grey silt on seasonally dry flatlands that are variably waterlogged or covered by very shallow water in the wet season. The areas are drained by shallow seasonal creeks, watersheds, drainage ditches, and rivulets running throughout the topography. The vegetation consists mainly of low growing herbs including many other Utricularia species, Byblis liniflora Salisb. (Byblidaceae), Drosera petiolaris R.Br. ex DC. (Droseraceae), Lindernia All. (Linderniaceae) and Mitrasacme Labill. (Loganiaceae) species. Scattered low shrubs also occur, as well as abundant orchids and Nepenthes mirabilis (Lour.) Druce (Nepenthaceae).

Phenology: flowering and fruiting are recorded from May to July.

Notes: comparison of specimens from the two regions where they occur reveals that although they are very similar, there are a number of leaf, trap, inflorescence, floral and fruit differences between them (Table 1). This possibly reflects the considerable distance between the populations (although this may in part also reflect undercollection due to the cryptic nature of the species). In particular, the bright pink area associated with the trap mouth (Figs 4c,d) seen in the Qld populations is unusual, or at least not a previously reported feature in the genus, and may serve as a visual attractant to potential prey. Similarly, the fruits in the Qld plants are tardily if at all dehiscent, apparently releasing the seeds only once the fruits have rotted. Nevertheless, given the small number of populations sampled and the need for more collections in the Northern Territory and Gulf of Carpentaria region of Queensland, these morphs are presently being regarded as conspecific pending more information. 
Table 1. Comparison of features differing between the two regions where the new species occurs

\section{Feature}

Traps: position

Traps: dorsal appendage

Traps: orifice

Peduncle

Bracts

Calyx lower lobe

Corolla upper lobe

Palate

Capsule and basal pore

\section{Northern Territory}

mainly on leaf bases, up to six per leaf

glabrous

hyaline

without verrucae

ovate-deltoid, acute to shortly acuminate

$0.5-0.75 \mathrm{~mm}$ long; $1 / 2$ as long as lower corolla lobe or less

apical margin rounded to retuse obvious, red-purple

dehiscent

\author{
Queensland \\ mainly on rhizome and \\ rhizoids, up to two on \\ leaf bases \\ papillate on margin \\ red \\ with light-catching, \\ hyaline verrucae \\ obovate, apically \pm \\ 3-lobed \\ 1-1.2 mm long; more \\ than $1 / 2$ as long as lower \\ corolla lobe \\ apical margin involute \\ absent or virtually so \\ indehiscent
}

Utricularia simmonsii is separated from other Utricularia spp. by its diminutive stature, peduncle lacking scales, 1-2(rarely 3 )-flowered inflorescence, small, red-purple hoodlike flowers without a spur. Other features that characterise the species are the dimidiate, unadorned traps, obloid, 5-6-colporate pollen and a globular placenta attached at its geometric centre.

The species belongs in Utricularia subgenus Utricularia and shares some features with members of both section Enskide and section Pleiochasia but fits neither section well. The lack of scales on the peduncle, solitary or paired flowers, and the capsule dehiscing by an elliptic pore (albeit functionally indehiscent in the Queensland plants) suggest affinities to section Pleiochasia. This section is distributed across Australia, New Zealand and New Caledonia and includes 25 northern Australian species among them U. capilliflora F.Muell., U. hamiltonii F.E.Lloyd, U. holtzei F.Muell., and U. rhododactylos P.Taylor. However, the unadorned traps with a lateral orifice, the obloid, 5-6-colporate pollen and the globular placenta attached at its geometric centre suggest they it is also allied with section Enskide, which comprises the two northern taxa Utricularia chrysantha and $U$. fulva

Nevertheless, $U$. simmonsii is distinctive by possessing an open, hood-like corolla which clearly displays the anthers and stigma. The unique floral structure, especially the lack of a spur and the open-throated corolla makes it different not only from most other Utricularia species, but Lentibulariaceae in general, which are characterised in part by a basally spurred or saccate lower lip. This, combined with other unique shared features such as seed morphology, glandular hair types and position, and trap anatomy which are discussed below in more detail, justifies the erection of a new section to accommodate the species.

Etymology: the species is named in honour of Paul Simmons, schoolteacher, botanist, carnivorous plant and ant-plant enthusiast, who discovered the species in Queensland.

Conservation status: in the Northern Territory, the species is known from just 
two locations near Darwin. Although plants were locally abundant with hundreds of flowering stems per square metre, little is known of the true size and extent of populations. Plants are very cryptic and not easy to see by casual observation, even when flowering. In addition, as discussed further below, it is likely that survey effort directed at other Utricularia species is mistimed for detection of this taxon.

The possible threat posed to this species by sand mining is unclear. Curiously, the species is only known from abandoned sand mining scrapes at two localities. Generally, the poorly drained sandy soils in the Darwin area continue to be heavily exploited as a source of fine sand for building and construction (Doyle 2001) and the long term conservation status of the flora they support is of some concern. Field observation suggests that in some areas, sand mining has altered the local drainage to favour species that prefer deeper water and a longer period of inundation. On the available evidence, there is some indication that sand mining can favour this species by providing areas of sandy substrate that stay wet for longer into the dry season. On the other hand, no other populations have been found despite extensive survey work targeted at Utricularia species in similar habitat in the Darwin area, including a number of mined areas. However, given the apparent later fertile period of U. simmonsii (May-early July) there is some doubt as to whether the timing of this survey effort was appropriate to detection of this species. In addition, areas of similar habitat extend to the east of Darwin to as far as Cobourg Peninsula and Maningrida, including Kakadu National Park. These areas have not been intensively surveyed at an appropriate scale or time of year. Experience with other apparently restricted taxa suggests that the species is very likely to be found elsewhere when suitable habitat is surveyed using an appropriate methodology.

The known populations occur on vacant free hold land which is proposed to become part of a bore field for the extraction of potable ground water for the City of Darwin and on the Howard River Hunting Reserve. In the short term, it appears it is at least offered some protection from clearing for residential or horticultural development, although the likely impacts of any adjacent development on site drainage and water quality are unknown. It is not anticipated that increased extraction of ground water will affect the species, as it is likely more influenced by the seasonal abundance of surface water. The Howard River Hunting Reserve has a history of surface mining for the extraction of sand, but it is not known if further mining is planned. The area is also used for waterfowl hunting in season, and for recreational $4 \mathrm{wd}$ driving.

In far north Queensland, Utricularia simmonsii is considered locally abundant at its three known locations and currently not under threat. The Tozer's Flat locality is presently protected from development and/or mining as it is situated c. $4 \mathrm{~km}$ to the $\mathrm{N}$ of Mt Tozer and c. $2.5 \mathrm{~km}$ to the $\mathrm{W}$ of North Pap and South Pap, well within the boundaries of the Iron Range National Park

Nevertheless, using IUCN (2001) Red list categories and guidelines, this species cannot be considered adequately surveyed and a conservation code of Data Deficient is thus recommended. However, given the uncertainty regarding the impact of further development of the rural area on the only known NT populations of this species, it requires interim protection until further survey is conducted and the species can be reassessed against IUCN criteria. 


\section{Utricularia section Minutae Lowrie, Cowie \& Conran, sect. nov.}

Herbae minutae. Vesiculae nudae vel glandulis sessilibus dispersis; appendix dorsalis singula; saetae irretitantes papillatae. Corolla cucullata; calcar deficiens; labium inferum integrum limbo diminuto. Stamina et stylus per corollam inclusus attamen conspicuus. Pollinia obloidea, 5-6-colporata. Ovarium placenta globulari in centro geometrico affixa. Capsula poro ventrali longitudinali instructa. Semina testa longitudinaliter torquato-striata.

Minute herbs. Bladders naked or with scattered sessile glands; with a single dorsal appendage; trapping hairs papillate; threshold glands 1-armed, internal glands bifid, arms ellipsoid and ovoid, c. 3 times as long as wide. Corolla hooded, lacking a nectary spur or a closed throat; lower lip lacking lateral lobes or an expanded pollinator landing apron. Stamens and style fully enclosed by corolla, but clearly visible. Pollen obloid, 5-6-colporate. Placenta globular, attached at its geometric centre. Capsule with a ventral longitudinal pore. Seeds with elongated cells, appearing longitudinally swirled and striated.

\section{Type species. U. simmonsii Lowrie, Cowie \& Conran}

The relationships of the section are uncertain, although it bears some similarities in trap structure to the native sect. Enskide, as well as to the mainly South American sects. Benjaminia, Stomoisia and Stylotheca in lacking lateral appendages or ventral wings, and in the presence of papillae (Fig. $4 \mathrm{~d}$ ). In addition, although the sampled members of Benjaminia and Stomoisia were part of the same broader clade in molecular analyses (Jobson \& Albert 2002, Jobson et al. 2003, Müller et al. 2004, Müller \& Borsch 2005), they did not form a monophyletic lineage. This makes naked bladders with a slight dorsal bulge (Figs 2d, 3c-d, 4a) a paraphyletic character (Jobson \& Albert 2002), and thus not necessarily grounds for placing $U$. simmonsii within, or relating it closely to any existing section.

The extreme reduction of the spur is uncommon in the genus. This character is shared only by the African $U$. rigida Benj. and $U$. tetraloba $P$. Taylor. In these species, the spur region is shallowly saccate whereas in $U$. simmonsi the spur is virtually absent.

Seed and internal trap gland characters are taxonomically important in the genus (Thor 1988, Taylor 1989) and there are also some similarities in seed sculpturing to the above groups, although the fingerprint-like pattern in sect. Minutae differs from all of the others (Figs $2 \mathrm{~h}, 3 \mathrm{j}$ ). Similarly, the internal trap glands most closely resemble the pattern seen in sect. Stomoisia, with ovoid 1-armed threshold cells (Fig. 4c) and the remainder bifid (Fig. 4b). Nevertheless, there are again too many floral and other differences between sects Minutae and Stomoisia to warrant its inclusion in the latter.

The presence and location of stipitate glandular hairs can be taxonomically important (Taylor 1989), although the significance of the structures is little understood. In $U$. simmonsii there are scattered sessile glands on the outside of the traps (Fig. 4d). The peduncle is \pm glabrous, with raised longitudinal verrucae scattered over the surface which shine silver in sunlight.

Pollen morphology is generally consistent within sections in Utricularia and regarded as having considerable taxonomic importance (Taylor 1989). sect. Minutae has 5-6colporate pollen, similar to sect. Enskinde (4-7 colporate), whereas sect. Pleiochasia has species with 3-4-colporate grains. Nevertheless, lower aperture numbers (3-8) are 
characteristic of the less derived members of the genus and occur in at least 11 sections making up the basal clades U1-4 of Jobson et al. (2003), suggesting that the feature is plesiomorphic and not strongly indicative of affinity.

Fruit dehiscence is another taxonomically important characteristic in Lentibulariaceae with 17 different patterns recognised, many of which have diagnostic potential at the sectional level (Taylor 1989). sect. Minutae has fruits with a single, ventral longitudinal elliptic pore (Taylor's Type E), but although the sutures are prominent in near-mature fruits, once the fruit dries they effectively disappear and the fruits remain enclosed by the persistent sepals and are indehiscent (at least in the Qld populations). Taylor noted that Type E fruits were almost universal in sect. Pleiochasia, but also found that they were the most common type, occurring in a wide range of Utricularia species. Nevertheless, this feature is apparently plesiomorphic within the genus (Jobson et al. 2003), making it of limited phylogenetic value. Similarly, sutureless fruits are known in some members of sects. Pleiochasia and Utricularia, and as Taylor (1989) observed, even some species with apparent suture lines may be functionally indehiscent. In contrast, species in sect. Enskinde dehisce by a single ventral pandurate pore, a unique feature in the genus which differentiates them from sect. Minutae, despite their trap and pollen similarities.

Overall, sect. Minutae seems to be closer on morphology to members of subgen. Bivalvia sensu Müller and Borsch (2005), although this requires molecular analysis to confirm, as well as wider comparisons with other taxa, especially the under-sampled northern Australian members of the family. Nevertheless, because sect. Minutae shows intermediacy in characters between several different sections in the genus, its precise affinities are uncertain, pending the results of ongoing morphological and molecular studies.

\section{Key to the Utricularia species in tropical Australia}

The key is derived from Taylor (1989) and the species are numbered according to his treatment to allow reference to descriptions there. Except where indicated, taxa occur in all regions (Western Australia, Northern Territory and Queensland). Species endemic to a particular state are indicated by an 'e' after the state abbreviation.

1 Plants free-floating or suspended in water; leaves usually much divided; bracteoles usually absent

1* Plants attached to substrate; leaves entire or 1-2(3)-divided; bracteoles usually present

2 Inflorescence stem with a whorl of ellipsoid floats above middle 3

$2^{*}$ Inflorescence stem without a whorl of floats or with narrowly fusiform floats at, or near the base

3 Floats shortly stipitate; calyx smaller than the capsule; seeds lenticular. 193 U. muelleri

$3 *$ Floats sessile; calyx larger than capsule; seeds prismatic, winged 192 U. stellaris

4 Corolla pink; spur long and slender; bracts ovate 23 U. tubulata

$4^{*}$ Corolla yellow; spur conical to narrowly conical; bracts broadly ovate to orbicular 5

5 Ultimate leaf segments 2-8; upper corolla lip larger than lower 179 U. gibba

$5^{*}$ Ultimate leaf segments 20-80; upper corolla lip smaller than lower 6 
6 Primary leaf divisions more than 2; scales absent; corolla pubescent outside

6* Primary leaf divisions 2; scales present on peduncle; corolla glabrous outside

7 Peduncle twining

184 U. australis

7 Peduncle erect, not twining 8

8 Corolla pale mauve, 3-4 mm long (NT, Qld) 10

$8^{*}$ Corolla yellow, c. 5-15 mm long 115 U. foveolata

9 Corolla about $5 \mathrm{~mm}$ long, pale yellow (NT) 108 U. circumvoluta

9* Corolla 10-15 mm long, bright yellow (NT) 84 U. involvens

10 Corolla with 2 vertical filiform lobes 11

$10^{*}$ Corolla lacking 2 vertical filiform lobes 14

11 Capillary lobes arising laterally from the corolla lower lip base; flowers solitary ............. 12

$11^{*}$ Capillary lobes arising from the corolla upper lip apex; flowers 1 or 3-5 13

12 Corolla lower lip reduced to 3 minute teeth; apex of spur rounded (WA e)

36 U. antennifera

$12^{\star}$ Corolla lower lip a well developed triangular lobe $1 / 3$ or more times length of spur, lateral lobes minute or absent; spur apex emarginate (WA, NT) 35 U. dunstaniae

13 Corolla lower lip 5-lobed; flowers solitary (NT e) 33 U. capilliflora

$13^{\star}$ Corolla lower lip 3-lobed; inflorescence 2-5-flowered (WA, NT) 34 U. dunlopii

14 Scales present on peduncle 15

$14^{\star}$ Scales absent 26

15 Scales and bracts basifixed, bracteoles present 16

$15^{\star}$ Scales and bracts medifixed (or nearly so), bracteoles present or absent 22

16 Corolla white or mauve 17

$16^{\star}$ Corolla yellow 19

17 Corolla lower lip shallowly 3-lobed 37 U. minutissima ${ }^{*}$

$17^{\star}$ Corolla lower lip entire, rounded or retuse 18

18 Bracts more or less equal in width to bracteoles; spur conical, apex shortly and acutely bidentate (Qld, southern Aust.) ..... 40 U. lateriflora

$18^{*}$ Bracts much wider than bracteoles; spur narrowly conical, apex acute 92 U. uliginosa

19 Corolla spotted with dark red; upper lip with 2 broad lobes (NT e) 81 U. fulva

$19^{\star}$ Corolla unspotted, but nerves may be red or brown; upper lip entire or emarginate ..... 20

20 Corolla lower lip 4-lobed; bracts cordate at base 80 U. chrysantha

$20 *$ Corolla lower lip entire or shallowly 2 -lobed; bracts not cordate 21

21 Corolla $6-10 \mathrm{~mm}$ long, upper lip narrower than the calyx; inflorescence $3-30 \mathrm{~cm}$ tall 82 U. bifida

$21^{\star}$ Corolla $10-15 \mathrm{~mm}$ long, upper lip wider than the calyx; inflorescence $25-55 \mathrm{~cm}$ tall (NT) 83 U. odorata

22 Corolla pale yellow; scales often ciliolate (NT) 165 U. subulata

$22^{\star}$ Corolla white or blue to purple; scales glabrous 23

23 Bracteoles present; corolla lower lip entire or obscurely lobed; leaves entire 43 U. caerulea

$23^{\star}$ Bracteoles absent; corolla lower lip with 2 well developed lobes; leaves divided 24 
24 Corolla 10-25 mm long, spur 7-15 mm long; bracts 3-4 mm long (WA, NT)

174 U. leptoplectra

$24^{*}$ Corolla 4-10 mm long; spur 3-10 $\mathrm{mm}$ long; bracts $2.5 \mathrm{~mm}$ long or less 25

25 Corolla dark blue-violet, $7-10 \mathrm{~mm}$ long; spur about as long as lower lip; leaf segments opposite (southern Qld)

175 U. biloba

$25^{*}$ Corolla white or pale, 3-6 mm long; spur longer than lower lip; leaf segments alternate 173 U. limosa

26 Corolla lower lip 5-lobed 27

$26^{*}$ Corolla lower lip entire, crenate or 2-4-lobed 30

27 Corolla white 28

$27^{\star}$ Corolla pink or mauve 29

28 Corolla 4-8 $\mathrm{mm}$ wide (NT e) 30 U. holtzei

$28^{*}$ Corolla about $2 \mathrm{~mm}$ wide 29 U. quinquedentata

29 Corolla upper lip shorter than the upper calyx lobe; base of lower lip without ridges (NT e) 32 U. cheiranthos

$29^{*}$ Corolla upper lip longer than the upper calyx lobe; base of lower lip with 4 rounded ridges (NT e)

31 U. rhododactylos

30 Corolla $4 \mathrm{~mm}$ long or less 31

$30^{\star}$ Corolla $6 \mathrm{~mm}$ long or more 32

31 Corolla c. $3 \mathrm{~mm}$ long, white to yellow, spur well developed and slightly longer than lower lip (Qld e) 28 U. albiflora

$31^{*}$ Corolla $1.5 \mathrm{~mm}$ long or less, dark pink to red, spur greatly reduced, apparently absent (NT, Qld)

U. simmonsii

32 Bracts and bracteoles medifixed (or nearly so), connate below the point of attachment and forming a tube around peduncle

$32 *$ Bracts and bracteoles medifixed or basifixed, when medifixed, free below the point of attachment and not forming a tube around peduncle

33 Corolla lower lip with 3 equal, narrow oblong-obovate lobes, white to pale mauve (WA e)

$33^{*}$ Corolla lower lip entire or obscurely 3 -crenate, mauve (WA, NT)

16 U. georgei

34 Peduncle hairy, at least at base

15 U. kimberleyensis

$34^{*}$ Peduncle glabrous, at most minutely papillose at base 35

35 Bracts and bracteoles ciliate; bracts basifixed 38

$35^{\star}$ Bracts and bracteoles not ciliate; bracts basifixed or medifixed 24 U. lasiocaulis

36 Corolla pale mauve, lower lip of 3 long oblong lobes; bracts medifixed (NT e)

25 U. kamienskii

$36^{*}$ Corolla mauve to purple, lower lip of 3 short rounded lobes; bracts basifixed or medifixed 37

37 Flowers usually solitary; upper lip constricted near base, upper part elliptic, apex emarginate (WA e)

26 U. kenneallyi

$37^{\star}$ Flowers 2-4, rarely 1 ; upper lip constricted in centre, upper part oblong, apex more or less deeply bifid (WA, NT)

27 U. leptorhyncha

38 Corolla lower lip distinctly 3 -lobed 39

$38^{\star}$ Corolla lower lip entire or obscurely $2-4$-lobed 40

39 Lobes of lower lip as long as wide ( $\left.\mathrm{WA}^{\ddagger}, \mathrm{NT}\right)$ 19 U. arnhemica

$39^{*}$ Lobes of lower lip 3 times longer than wide (WA e) 20 U. tridactyla 
40 Corolla spur not widely divergent from lower lip, erect, broadly obloid at base tapering to a dorsally flattened, narrow apex ( $\left.\mathrm{WA}^{\dagger}, \mathrm{NT}\right)$ 21 U. singeriana

$40^{*}$ Corolla spur diverging widely from lower lip, usually deflexed and narrow, apex acute to obtuse

41 Spur broadly conical, obtuse, distinctly longer than lower lip; flowers $1(-3)\left(\mathrm{WA}, \mathrm{NT}^{\wedge}\right.$ ) 22 U. fistulosa

$41^{\star}$ Spur narrowly conical, cylindrical or cylindrical-subulate, straight or tapering gradually, equal to or shorter than lower lip; flowers 1-9 42

42 Flowers 2-9, rarely 1; bracts often with the base more or less swollen, sometimes free .. 43

$42 *$ Flowers always solitary; bracts membranous to herbaceous 44

43 Palate with 2-3 prominent ridges; apex of upper lip rounded to emarginate; leaf apex rounded to acute (Qld, southern Aust.) 10 U. dichotoma

$43^{*}$ Palate ridges not prominent; apex of upper lip shortly bilobed to emarginate; leaf apex subulate (NT e) 18 U. triflora

44 Corolla $6-12 \mathrm{~m}$ long, usually mauve, apex of upper lip divided into two deltoid lobes, lower lip 4-angled (WA $\left.{ }^{\circ}, \mathrm{NT}\right)$ 17 U. hamiltonii

$44^{\star}$ Corolla $15-20 \mathrm{~mm}$ long, white or very pale violet, apex of upper lip truncate to emarginate, lower lip transversely elliptic (Qld e)

11. U. terrae-reginae

"There is also another very small flowered (c. $2 \mathrm{~mm}$ ), apparently new taxon known from further north on Cape York (J. Clarkson pers. comm.) with purple, spurred, palated flowers similar to a tiny version of the widespread $U$. minutissima Vahl., but which requires further study to determine its identity and affinities.

+ There is some doubt that this name has been applied correctly to WA specimens and the material is currently under study.

₹ This taxon is now recorded for WA (R. Barrett pers. comm.; FloraBase 2007).

Utricularia fistulosa has recently been recorded (K.G.Brennan 7275) from Macadam Range, in NT.

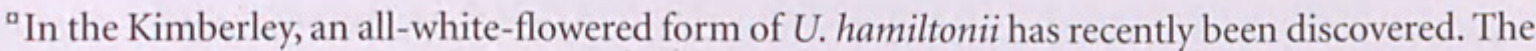
typical mauve-flowered $U$. hamiltonii common in the Northern Territory was not found at the Kimberley location (R. Barrett pers. comm.).

\section{Acknowledgments}

Judy Egan first collected $U$. simmonsii and brought it to the attention of staff at DNA. Bob Harwood made collections over a number of years and his interest and encouragement led in part to description of the species. Paul Simmons is similarly thanked for his significant help through field collections, observations, and discussions while stationed as a schoolteacher in Lockhart River until 2005. Dale Dixon and Kym Brennan commented on an earlier version of the manuscript. Raelee Kerrigan provided valuable comments on the proposed conservation status of the species in the NT. The School of Earth and Environmental Sciences at The University of Adelaide is thanked for the provision of facilities to undertake part of the research. 


\section{References}

Doyle N (2001) Extractive minerals within the outer Darwin area. Darwin, Report 14. Northern Territory Geological Survey.

IUCN (2001) IUCN Red List categories and criteria: Version 3.1. IUCN Species Survival Commission. (IUCN: Gland and Cambridge)

Jobson RW \& Albert VA (2002) Molecular rates parallel diversification contrasts between carnivorous plant sister lineages. Cladistics 18: 127-136.

Jobson RW, Playford J, Cameron KM \& Albert VA (2003) Molecular phylogenetics of Lentibulariaceae inferred from plastid $r p s 16$ intron and trnL-F DNA sequences: implications for character evolution and biogeography. Systematic Botany 28: 157-171.

Lowrie A (1998a) Carnivorous Plants of Australia, vol. 3. (University of Western Australia Press: Perth)

Lowrie A (1998b) A new species of Utricularia (Lentibulariaceae) from the south-west of Western Australia. Nuytsia 12: 37-41.

Lowrie A (2002) Utricularia petertaylorii (Lentibulariaceae), a new species from the south-west of Western Australia. Nuytsia 14: 405-410.

Müller K \& Borsch T (2005) Phylogenetics of Utricularia (Lentibulariaceae) and molecular evolution of the $t r n \mathrm{~K}$ intron in a lineage with high substitutional rates. Plant Systematics and Evolution 250: 39-67.

Müller K, Borsch T, Legendre L, Porembski S, Theisen I \& Barthlott W (2004) Evolution of Carnivory in Lentibulariaceae and the Lamiales. Plant Biology 6: 477-490.

Taylor P (1989) The genus Utricularia - a taxonomic monograph. Kew Bulletin Additional Series XIV. (HMSO: London).

Thor G (1988) The genus Utricularia in the Nordic countries with special emphasis on U. stygia and U. ochroleuca. Nordic Journal of Botany 8: 219-225.

Williams MAJ (1969) Geomorphology of the Adelaide-Alligator Area. Pp. 71-94 in Story R, Williams MAJ, Hooper ADL, O'Ferrall RE \& McAlpine JR (eds) Lands of the AdelaideAlligator area, Northern Territory. Land Research Series No. 25. (CSIRO: Melbourne).

Woinarski JCZ, Hempel C, Cowie I, Brennan K, Kerrigan R, Leach G \& Russell-Smith J (2006) Distributional patterning of plant species endemic to the Northern Territory, Australia. Australian Journal of Botany 26: 627-640. 


\section{$2 \mathrm{BHL}$ Biodiversity Heritage Library}

Lowrie, Alan, Cowie, I. D., and Conran, John. 2008. "A new species and section of Utricularia (Lentibulariaceae) from northern Australia." Telopea: Journal of plant systematics 12(1), 31-46. https://doi.org/10.7751/telopea20085802.

View This Item Online: https://www.biodiversitylibrary.org/item/266864

DOI: https://doi.org/10.7751/telopea20085802

Permalink: https://www.biodiversitylibrary.org/partpdf/305757

\section{Holding Institution}

The Royal Botanic Gardens and Domain Trust, New South Wales, Australia

\section{Sponsored by}

Atlas of Living Australia

\section{Copyright \& Reuse}

Copyright Status: In copyright. Digitized with the permission of the rights holder.

Rights Holder: The Royal Botanic Gardens and Domain Trust, New South Wales, Australia License: http://creativecommons.org/licenses/by-nc-sa/4.0/

Rights: http://biodiversitylibrary.org/permissions

This document was created from content at the Biodiversity Heritage Library, the world's largest open access digital library for biodiversity literature and archives. Visit BHL at https://www.biodiversitylibrary.org. 